\title{
Removal of Nitrogen Dioxide and Sulfur Dioxide from Air Streams by Absorption in Urea Solution
}

\author{
Mahmood M. Barbooti ${ }^{1}$, Neran K. Ibraheem ${ }^{2}$, Awni H. Ankosh ${ }^{2}$ \\ ${ }^{1}$ School of Applied Sciences, Baghdad, Iraq; ${ }^{2}$ Department of Chemical Engineering, University of Technology, Baghdad, Iraq. \\ Email: aldhaherim@mail.montclair.edu,neran_ibrahim@yahoo.com,awni_ankoosh@hotmail.com \\ Received November $25^{\text {th }}, 2010$; revised January $13^{\text {th }}, 2011$; accepted March $16^{\text {th }}, 2011$.
}

\begin{abstract}
The study focuses on the absorption rates of $\mathrm{NO}_{2}, \mathrm{SO}_{2}$ and a mixture of these two acid gases into urea solution in packed bed column. The absorption rate was studied as a function of absorbent temperature, urea concentration and acid gas concentration. The influence of liquid temperature between $10-40^{\circ} \mathrm{C}$, urea concentration between $0.1-0.5 \mathrm{M}$ and acid gas concentration $\mathrm{NO}_{2}$ between $100-1000 \mathrm{ppm}\left(191-1910 \mathrm{mg} / \mathrm{m}^{3}\right), \mathrm{SO}_{2}$ between $500-2500 \mathrm{ppm}(1310$ $\left.6530 \mathrm{mg} / \mathrm{m}^{3}\right)$ were investigated. The mass gas flow rate of $20.646\left(\mathrm{~kg} / \mathrm{m}^{2} . \mathrm{min}\right)$ at $25^{\circ} \mathrm{C}$ and the absorption rate were determined by measuring the $\mathrm{NO}_{2}$ and $\mathrm{SO}_{2}$ concentrations in the inlet and outlet streams of the absorptioncolumn. The absorption rate of $\mathrm{SO}_{2}$ increases with the decrease of temperature of absorbent (urea solution) and with the increase of the urea concentration. The presence of $\mathrm{NO}_{2}$ in the effluent gas stream lowers the absorption rate of $\mathrm{SO}_{2}$ in urea solution due to the fast reaction of $\mathrm{NO}_{2}$ with urea as compared with $\mathrm{SO}_{2}$. The absorption rate of $\mathrm{NO}_{2}$ decreases as the urea concentration exceeds $0.4 \mathrm{~mol} / \mathrm{l}$ and for $\mathrm{NO}_{2}$ gas concentration of $100 \mathrm{ppm}$ due to the decrease the diffusivity of the gas. The experimental data were analyzed using dimensionless analysis to find the correlation of mass transfer coefficient in the packed column $S h(H / d p)^{1.2}=4.19^{*} 10^{-2} *\left(G^{\prime} d p / \mu_{g}\right)^{0.87}\left(\mu_{g} / \rho_{g} D_{A B}\right)^{0.60}$ The results confirmed the hypothesis that the absorption is accompanied with chemical reaction. Also it is found the increasing the temperature of absorbent solution the absorption rate of two gases is decreases. The mass transfer coefficient models are in good agreements with the Kramer's equation.
\end{abstract}

Keywords: Sulfur Dioxide Removal, Nitrogen Dioxide Removal, Column Absorption, Removal of Acid Gases, Air Pollution Prevention

\section{Introduction}

The harmful effects of the sulfur dioxide, $\mathrm{SO}_{\mathrm{x}}$ and nitrtogen dioxide, $\mathrm{NO}_{\mathrm{x}}$, gases emissions in dense industrial and urban areas receive increasing attention especially where their production exceeds neutralization and dispersion forces [1]. Of the major contributors nitric acid plants contribute the most $\mathrm{NO}_{2}$ to the environment [2]. The release of $\mathrm{SO}_{\mathrm{x}}$ can be controlled by ammonia injection which relies solely on gas phase reaction in the presence of moisture to produce ammonium sulfate solid particles that can be captured by any other particulate collection device [3]. Heterogeneous reduction process of $\mathrm{SO}_{\mathrm{x}}$ by hydrogen sulfide into sulfur can be done in the presence of suitable solid phase catalysts. Methane can be used for the reduction of $\mathrm{SO}_{\mathrm{x}}$ into hydrogen sulfide on alumina as the catalyst. The hydrogen sulfide produced by this method is captured by amine scrubbing of the reduced gas stream. The higher concentration of sulfide obtained by heating the amine salt may then be easily and economically converted to elemental sulfur via the Claus process [4].

Catalytic oxidation of $\mathrm{SO}_{\mathrm{x}}$ with air, via the heterogeneous contact process or the homogeneous chamber process, also serves to improve the collection efficiency of the $\mathrm{SO}_{2}$. Also the collection of $\mathrm{SO}_{3}$ by direct absorption into water is extremely efficient and the produced sulfuric acid is a salable commodity [5]. The scrubbing of $\mathrm{SO}_{2}$ in dilute ammonium hydroxide gives ammonium sulfate that can be a valuable constituent of fertilizer formulations [6]. The Wellman-lord process uses the effective sodium sulfite equilibrium to capture sulfur dioxide from flue gases [7]. Most of the sodium bisulfite produced is converted back to sodium sulfite which can be crystallized out, dried and sold as wood pulping chemical. The citrate process in which much development work has been invested by the U.S Bureau of mines and by Pfizer use an aqueous solution of citric acid to 
capture $\mathrm{SO}_{2}$. Uncomplexed citric acid can be regenerated thermally to obtain stripped citrate solution and stream of up to $90 \% \mathrm{SO}_{2}$ at this stage [8].

The $\mathrm{SO}_{2}$ gas may be entrapped in molten alkali carbonate at about $425^{\circ} \mathrm{C}$ [9]. Limestone or lime slurry in water is used in a suitably designed scrubber in an effective and relatively low cost $\mathrm{SO}_{2}$ removal method. The affinity of the activated carbon for the acid gases is, in increasing order, $\mathrm{CO}_{2}<\mathrm{SO}_{2}<\mathrm{NO}_{2}$, [10]. The use of powdered limestone injection is applied to remove $\mathrm{SO}_{2}$ from flue gases from coal burning. The $\mathrm{SO}_{2}$ reacts with solid lime to form solid particles of calcium sulfite and calcium sulfate which are captured in electrostatic precipitators [11].

Three methods are used to control and reduce $\mathrm{NO}_{\mathrm{x}}$ emission, namely: absorption, selective catalytic reduction and non-sélective catalytic reduction [12]. For methane reduction, the polluted gas stream is preheated to about $400^{\circ} \mathrm{C}$ and then blended with the appropriate proportion of methane before passage over platinum or palladium catalytic surface for reduction [13]. Selective catalytic abatement uses a catalyst and ammonia fuel to reduce $\mathrm{NO}_{\mathrm{x}}$ in preference to combustion with the much higher levels of oxygen in the gas at temperatures in the range $210-410^{\circ} \mathrm{C}$. Slight excess of ammonia may be used to leave 5 - 20 (ppmv) in the treated gas stream. Zhang et al., 2008 [14], studied the $\mathrm{NO}_{x}$ removal from simulated flue gas by chemical absorption-biological reduction integrated approach in a biofilter. They concluded that maximum elimination capacity (18.78 g. NO $\mathrm{m}^{-3} \mathrm{~h}^{-1}$ ) was achieved at a loading rate of $28.68 \mathrm{~g} \cdot \mathrm{NO}$ $\mathrm{m}^{-3} \mathrm{~h}^{-1}$ and maintained $5 \mathrm{~h}$ operation at the steady state.

The aim of the present work is at studying the effects of the operation parameters on the absorption of $\mathrm{SO}_{2}$ and $\mathrm{NO}_{2}$ from air streams using dilute urea solution. The operating variables studied are: concentration of the two gases in air, concentration of absorbent (urea) solution and temperature of absorbent solution

\section{Materials and Methods}

\subsection{Experimental Set up}

Figure 1 shows a photograph of the bench scale system designed for the absorption of gases. The rig consisted of three sections: generation, absorption and analysis sections.

For the generation of the gases a three neck QVF 5 L-flask is connected at its upper part to a glass burette $(100 \mathrm{ml})$ capacity which contains sulfuric acid or nitric acid. The inlet of the generation section was connected to a compressed air source.

The absorption section was a packed column of $7.5 \mathrm{~cm}$ inside diameter and $50 \mathrm{~cm}$ height, which is packed with glass Rashig rings (6 $\mathrm{mm}$ inside diameter). The height of packing is $(45 \mathrm{~cm})$. Counter current flow of the gas mixture was maintained at a mass flux of gases $\left(G^{\prime}=20.64\right.$ $\mathrm{kg} / \mathrm{m}^{2} \cdot \mathrm{min}$ ), and the mass flux of absorbent liquid downward $=188 \mathrm{~kg} / \mathrm{m}^{2} \cdot \min$. The used values for the gas flow rate and liquid flow rate was checked with loading, flooding and pressure drop calculation in the column. Calculations are given in appendix C. The pump is used to rises the absorbent solution from the 15 liter capacity (QVF) vessel supported at the middle of column. The rig was insulated with glass wool to maintain the absorbent temperature nearly constant.

Calibrated rotameters were used to measure the air and solvent flow rates.

\subsection{Chemicals}

For the generation and detection of $\mathrm{SO}_{2}$, Sodium sulfite, $\mathrm{Na}_{2} \mathrm{SO}_{3}$ was supplied from Merck, Germany. Sulfuric acid, $\mathrm{H}_{2} \mathrm{SO}_{4}$, iodine, $\mathrm{I}_{2}$, Iodine ampoule, $0.1 \mathrm{~N}$, potassium iodide, KI, starch and Sodium thiosulfate ampoule, $0.1 \mathrm{~N}$ were analytical grade reagents from BDH, England. Urea was an industrial grade product from a local fertilizer factory.

For the generation and detection of $\mathrm{NO}_{2}$, nitric acid, sodium hydroxide, phenolphthalein and copper were supplied from BDH, England; Hydrogen peroxide, $\mathrm{H}_{2} \mathrm{O}_{2}$ was a local product.

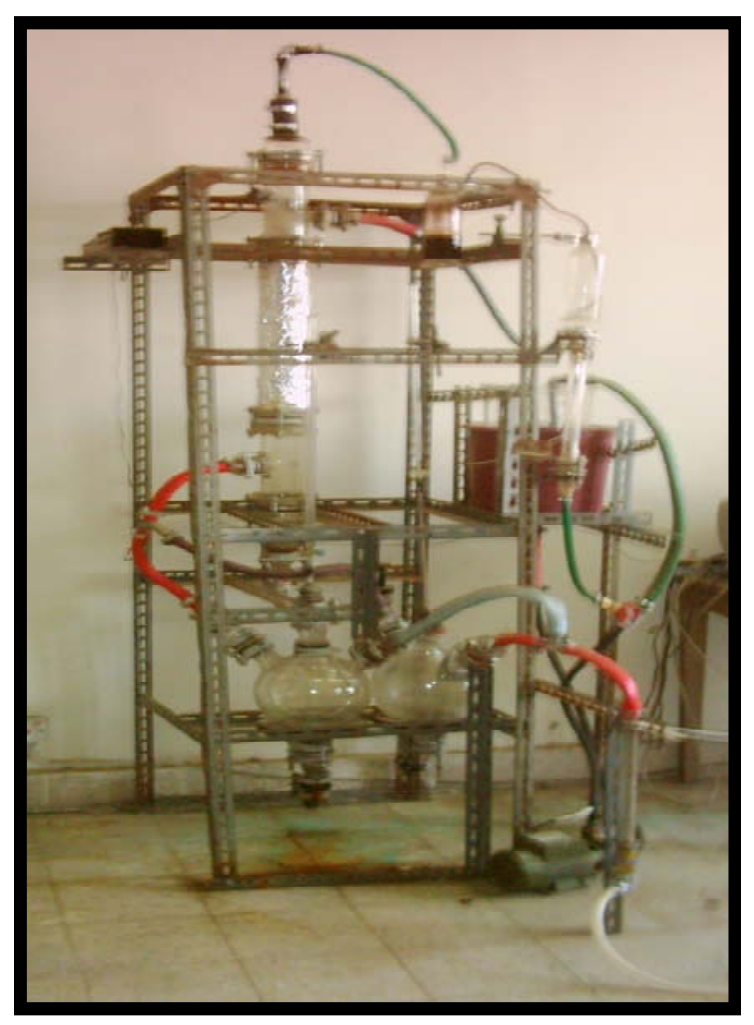

Figure 1. A photograph of the experimental Rig. 


\subsection{Procedures}

$\mathrm{SO}_{2}$ Generation was carried out by the reaction of sodium sulfite solution with sulfuric acid using various acid concentrations $(5-23 \mathrm{wt} \%)$. An air stream at constant mass flux of $\left(20.64 \mathrm{~kg} / \mathrm{m}^{2} \cdot \mathrm{min}\right)$ was then passed through the reaction vessel to transport the generated $\mathrm{SO}_{2}$ gas towards the packed bed absorber. Urea solution was allowed to move downward from the top of the column at constant mass flux $\left(188 \mathrm{~kg} / \mathrm{m}^{2} \cdot \mathrm{min}\right)$.

$\mathrm{NO}_{2}$ was generated by the reaction of copper with nitric acid of various concentrations (5 - $35 \mathrm{wt} \%)$. An air stream at constant mass flux of $\left(20.64 \mathrm{~kg} / \mathrm{m}^{2} \cdot \mathrm{min}\right)$ was then passed through the reaction vessel to transport the generated $\mathrm{NO}_{2}$ gas towards the packed bed absorber. Urea solution was allowed to move downward from the top of the column at constant mass flux $\left(188 \mathrm{~kg} / \mathrm{m}^{2} \cdot \mathrm{min}\right)$.

Generation of $\mathrm{SO}_{2}$ and $\mathrm{NO}_{2}$ mixture:

Two reaction vessels were used simultaneously to generate the two gases as in the procedure above and the gases were directed at the same time by the same air stream towards the absorption column. The outlet of the column was connected to two different traps containing the detection reagents of residual gases sequentially, where the first absorber trap contains iodine solution for $\mathrm{SO}_{2}$ and the second contains hydrogen peroxide for $\mathrm{NO}_{2}$.

\subsection{Measurements of Absorption Rate}

The weight of $\mathrm{SO}_{2}$ Absorbed was determined by measuring the residual amount by its quantitative reaction with iodine and titrating excess iodine with sodium thiosulfate. The number of iodine equivalents is equal to the residual $\mathrm{SO}_{2}$ in the trap.

The weight of $\mathrm{NO}_{2}$ absorbed by the quantitative reaction with hydrogen peroxide to form nitric acid which can be determined by titration with $0.01 \mathrm{~N} \mathrm{NaOH}$ solution using phenolphthalein as an indicator [15].

\subsection{Experimental Design}

Variables acting together may have greater or smaller effect than individual variables acting alone. A response surface can be most efficient fitted if proper attention is given to the choice of experimental design [16]. BoxWilson, composite rotatable design is common type of statistical experiments, especially applicable to optimization analysis.

The effect of three variables for each acid gas such as, liquid temperature, liquid concentration and concentration of $\mathrm{SO}_{2}$ and $\mathrm{NO}_{2}$ on the absorption rates were investigated and analyzed. The number of experiments needed according to design are 15 plus 5 experiments at the center point to estimate the experimental error.

For $\mathrm{SO}_{2}$ gas, the ranges of the operating variables are:
1) $\mathrm{SO}_{2}$ concentration, 500 - 2500 ppm (1310 - 6550 $\left.\mathrm{mg} / \mathrm{m}^{3}\right)=X_{1}$

2) Urea concentration, $0.1-0.5 \mathrm{~mol} / \mathrm{L}=X_{2}$

3) Liquid temperature, 10 to $40^{\circ} \mathrm{C}=X_{3}$

According to Equation (1) the relationships between the coded levels and the corresponding real variables as follows

$$
\begin{aligned}
X_{1 \text { coded }} & =\frac{\text { conc. } \mathrm{SO}_{2}-1500}{577.35} \\
X_{2 \text { coded }} & =\frac{\text { Urea.conc }(\mathrm{mol} / \mathrm{l})-0.3}{0.1154} \\
X_{3 \text { coded }} & =\frac{\text { Tempofsolution }\left({ }^{\circ} \mathrm{C}\right)-25}{8.66}
\end{aligned}
$$

For $\mathrm{NO}_{2}$ gas, the ranges of the operating variables are:

1) $\mathrm{NO}_{2}$ concentration, 100 - 1000 ppm (191 - 1910 $\left.\mathrm{mg} / \mathrm{m}^{3}\right)=\mathrm{X}_{1}$

2) Urea concentration, $0.1-0.5 \mathrm{~mol} / \mathrm{L}=\mathrm{X}_{2}$

3) Liquid temperature, 10 to $40^{\circ} \mathrm{C}=\mathrm{X}_{3}$

According to Equation (1) the relationships between the coded levels and the corresponding real variables are as follows

$$
\begin{aligned}
X_{1 \text { Coded }} & =\frac{\text { Conc. } \mathrm{NO}_{2}-550}{260} \\
X_{2 \text { coded }} & =\frac{\text { Conc.urea }-0.3}{0.1154} \\
X_{3 \text { Coded }} & =\frac{\text { Temp }\left({ }^{\circ} \mathrm{C}\right)-25}{8.66}
\end{aligned}
$$

\subsection{For $\mathrm{SO}_{2}$ and $\mathrm{NO}_{2}$ Gases}

1) $\mathrm{SO}_{2}$ concentration, $500-2500 \mathrm{ppm}(1310-6550$ $\left.\mathrm{mg} / \mathrm{m}^{3}\right)=X_{1}$

2) $\mathrm{NO}_{2}$ concentration, 100 - 1000 ppm (191 - 1910 $\left.\mathrm{mg} / \mathrm{m}^{3}\right)=X_{2}$

3) Urea concentration, $0.1-0.5 \mathrm{~mol} / \mathrm{L}=X_{3}$

4) Liquid temperature, 10 to $40^{\circ} \mathrm{C}=X_{4}$

$$
\begin{aligned}
X_{1 \text { coded }} & =\frac{\text { Conc. } \mathrm{SO}_{2}-1500}{500} \\
X_{2 \text { coded }} & =\frac{\text { Conc. } \mathrm{NO}_{2}-550}{225} \\
X_{3 \text { coded }} & =\frac{\text { Conc.urea }-0.3}{0.1} \\
X_{4 \text { coded }} & =\frac{\text { Temp }\left({ }^{\circ} \mathrm{C}\right)-25}{7.5}
\end{aligned}
$$

The values of the coded and real variables for the absorption experiments of $\mathrm{SO}_{2} / \mathrm{NO}_{2}$ mixtures are given in Table 1. 
Table 1. Coded and real variables for $\mathrm{SO}_{2}$ and $\mathrm{NO}_{2}$ absorption experiments.

\begin{tabular}{|c|c|c|c|c|c|}
\hline \multirow{2}{*}{ Run no. } & \multirow{2}{*}{$\begin{array}{c}\text { Coded Variables } \\
\mathbf{X}_{1} / \mathbf{X}_{2} / \mathbf{X}_{3} \mathbf{X}_{4}\end{array}$} & \multicolumn{4}{|c|}{ Real Variables } \\
\hline & & $\mathrm{ConSO}_{2}$ (ppm) & $\mathrm{ConcNO}_{2}$ (ppm) & Urea. Conc. (gmol/l) & Temp of Absorbent ${ }^{0} \mathrm{C}$ \\
\hline 1 & $+1 /+1 /+1 /+1$ & 2000 & 775 & 0.4 & 32.5 \\
\hline 2 & $-1 /+1 /+1 /+1$ & 1000 & 775 & 0.4 & 32.5 \\
\hline 3 & $+1 /-1 /+1 /+1$ & 2000 & 225 & 0.4 & 32.5 \\
\hline 4 & $+1 /+1 /-1 /+1$ & 2000 & 775 & 0.2 & 32.5 \\
\hline 5 & $+1 /+1 /+1 /-1$ & 2000 & 775 & 0.4 & 17.5 \\
\hline 6 & $-1 /-1 /-1 /-1$ & 1000 & 225 & 0.2 & 17.5 \\
\hline 7 & $+1 /-1 /-1 /-1$ & 2000 & 225 & 0.2 & 17.5 \\
\hline 8 & $-1 /+1 /-1 /-1$ & 1000 & 775 & 0.2 & 17.5 \\
\hline 9 & $-1 /-1 /+1 /-1$ & 1000 & 225 & 0.4 & 17.5 \\
\hline 10 & $-1 /-1 /-1 /+1$ & 1000 & 225 & 0.2 & 32.5 \\
\hline 11 & $+1 /+1 /-1 /-1$ & 2000 & 775 & 0.2 & 17.5 \\
\hline 12 & $+1 /-1 /+1 /-1$ & 2000 & 225 & 0.4 & 17.5 \\
\hline 13 & $+1 /-1 /-1 /+1$ & 2000 & 225 & 0.2 & 32.5 \\
\hline 14 & $-1 /-1 /+1 /+1$ & 1000 & 225 & 0.4 & 32.5 \\
\hline 15 & $-1 / 1 /-1 / 1$ & 1000 & 775 & 0.2 & 32.5 \\
\hline 16 & $-1 / 1 / 1 /-1$ & 1000 & 775 & 0.4 & 17.5 \\
\hline 17 & $2 / 0 / 0 / 0$ & 2500 & 550 & 0.3 & 25 \\
\hline 18 & $0 / 2 / 0 / 0$ & 1500 & 1000 & 0.3 & 25 \\
\hline 19 & $0 / 0 / 2 / 0$ & 1500 & 550 & 0.5 & 25 \\
\hline 20 & $0 / 0 / 0 / 2$ & 1500 & 550 & 0.3 & 40 \\
\hline 21 & $-2 / 0 / 0 / 0$ & 500 & 550 & 0.3 & 25 \\
\hline 22 & $0 /-2 / 0 / 0$ & 1500 & 100 & 0.3 & 25 \\
\hline 23 & $0 / 0 /-2 / 0$ & 1500 & 550 & 0.1 & 25 \\
\hline 24 & $0 / 0 / 0 /-2$ & 1500 & 550 & 0.3 & 10 \\
\hline 25 & $0 / 0 / 0 / 0$ & 1500 & 550 & 0.3 & 25 \\
\hline 26 & $0 / 0 / 0 / 0$ & 1500 & 550 & 0.3 & 25 \\
\hline 27 & $0 / 0 / 0 / 0$ & 1500 & 550 & 0.3 & 25 \\
\hline 28 & $0 / 0 / 0 / 0$ & 1500 & 550 & 0.3 & 25 \\
\hline 29 & $0 / 0 / 0 / 0$ & 1500 & 550 & 0.3 & 25 \\
\hline
\end{tabular}

\section{Results and Discussion}

The measurement concerned the study of the effect of the operation variables such as $\mathrm{SO}_{2}$ and $\mathrm{NO}_{2}$ level, urea concentration and operating temperature on the absorption rate of acid gas and consequently their removal.

The absorption rate of an acid gas $\left(\mathrm{NO}_{2}\right.$ or $\left.\mathrm{SO}_{2}\right)$ is expressed as the equivalent moles of $\mathrm{NO}_{2}$ or $\mathrm{SO}_{2}$ that react with urea solution per unit interface area per unit time. This absorption rates were calculated in accordance with the expressions of Weisweiler and Dieb [17]. The absorption rates values for $\mathrm{SO}_{2}$ and $\mathrm{NO}_{2}$ are listed in the Tables 2 and 3, respectively. The mass transfer coefficient for the packed bed column was estimated by using the design equation for dilute gas mixture [18].

\subsection{Effect of Operating Variables}

\subsubsection{Effect of Acid Gas Concentration}

Figure 2 shows the effect of $\mathrm{SO}_{2}$ concentrations on the absorption rate for various urea concentrations $(0.1-0.5$ $\mathrm{mol} / \mathrm{L}$ at fixed absorbent solution temperature of $25^{\circ} \mathrm{C}$. For $\mathrm{NO}_{2}$ the results are shown in Figure 3. The results indicate that the absorption rate increases as the $\mathrm{SO}_{2}$ concentration increases. This can be attributed to the greater driving force available as the $\mathrm{SO}_{2}$ concentration increased and consequently higher absorption rate are more easily attained. These results agree with published report of Basu et al. [19], where the rate of absorption increased directly with the driving force during the $\mathrm{SO}_{2}$ absorption in caustic soda and dimethylaniline solution.

The results of $\mathrm{NO}_{2}$ indicated that the absorption rate increases sharply as the concentration of the gas increases. This behavior may be expected because the reaction between $\mathrm{NO}_{2}$ and urea solutions in the liquid phase is very fast. These results confirm the findings of Lefer et al. [20].

Figure 4 shows the effect of $\mathrm{NO}_{2}$ concentrations on the absorption rate for various working temperatures (10 $-40^{\circ} \mathrm{C}$ ) at fixed urea concentration of $0.185 \mathrm{M}$. For $\mathrm{SO}_{2}$ the results indicated a similar trend. The absorption rate increases as the $\mathrm{SO}_{2}$ and $\mathrm{NO}_{2}$ concentrations in- creased. Also, these figures indicate that the absorption rate is more favored at lower temperatures. Thus the re- action rate is higher at lower temperatures because the diffusivity increasing with decreasing temperature. 
Table 2. Experimental results of $\mathrm{SO}_{2}$ absorption and values of interfacial area of packing.

\begin{tabular}{|c|c|c|c|c|c|c|}
\hline Run No. & $\begin{array}{c}\mathrm{SO}_{2} \text { input Conc., } \\
\text { ppm }\end{array}$ & $\begin{array}{l}\mathrm{SO}_{2} \text { Output } \\
\text { Conc., ppm }\end{array}$ & $a_{p}\left(m^{2} / m^{3}\right)$ & $\mathbf{a}\left(\mathbf{m}^{2}\right)$ & $\mathrm{Na} * 10^{-3}\left(\mathrm{~mol} / \mathrm{m}^{2} . \mathrm{s}\right)$ & $K_{G}\left(\mathrm{~kg} / \mathrm{m}^{3} \mathrm{~s}\left(\mathrm{kN} / \mathrm{m}^{2}\right)\right.$ \\
\hline 1 & 922.6 & 156.842 & 175.3678 & 0.073214 & 0.476972 & 0.000168352 \\
\hline 2 & 2077.6 & 276.3208 & 175.3678 & 0.073214 & 1.121972 & 0.000191671 \\
\hline 3 & 922.6 & 52.95724 & 175.4981 & 0.073268 & 0.541277 & 0.000271306 \\
\hline 4 & 2077.6 & 49.65464 & 175.4981 & 0.073268 & 1.262219 & 0.000354488 \\
\hline 5 & 922.6 & 204.7618 & 183.8415 & 0.076752 & 0.426515 & 0.000136429 \\
\hline 6 & 2077.6 & 386.2051 & 183.8415 & 0.076752 & 1.004968 & 0.000152494 \\
\hline 7 & 922.6 & 107.0216 & 183.9731 & 0.076807 & 0.484242 & 0.000195092 \\
\hline 8 & 2077.6 & 120.5008 & 183.9731 & 0.076807 & 1.162009 & 0.000257866 \\
\hline 9 & 500 & 130 & 180.1686 & 0.075218 & 0.224323 & 0.000124574 \\
\hline 10 & 2500 & 162.5 & 180.1686 & 0.075218 & 1.417175 & 0.000252774 \\
\hline 11 & 1500 & 170.835 & 180.0638 & 0.075174 & 0.806313 & 0.000201026 \\
\hline 12 & 1500 & 58.695 & 180.3642 & 0.0753 & 0.872884 & 0.000299381 \\
\hline 13 & 1500 & 17.952 & 171.2891 & 0.071511 & 0.945113 & 0.000430476 \\
\hline 14 & 1500 & 280.245 & 184.3118 & 0.076948 & 0.722887 & 0.000151648 \\
\hline 15 & 1500 & 111 & 180.1686 & 0.075218 & 0.84212 & 0.000240782 \\
\hline 16 & 1500 & 111 & 180.1686 & 0.075218 & 0.84212 & 0.000240782 \\
\hline 17 & 1500 & 111 & 180.1686 & 0.075218 & 0.84212 & 0.000240782 \\
\hline 18 & 1500 & 111 & 180.1686 & 0.075218 & 0.84212 & 0.000240782 \\
\hline 19 & 1500 & 111 & 180.1686 & 0.075218 & 0.84212 & 0.000240782 \\
\hline 20 & 1500 & 111 & 180.1686 & 0.075218 & 0.84212 & 0.000240782 \\
\hline
\end{tabular}

Table 3. Experimental results of $\mathrm{NO}_{2}$ absorption and values of interfacial area of packing.

\begin{tabular}{|c|c|c|c|c|c|c|}
\hline Run No. & $\begin{array}{c}\mathrm{NO}_{2} \text { input Conc., } \\
\text { ppm }\end{array}$ & $\begin{array}{l}\mathrm{NO}_{2} \text { Output } \\
\text { Conc., ppm }\end{array}$ & $a_{p}\left(m^{2} / m^{3}\right)$ & $\mathbf{a}\left(\mathbf{m}^{2}\right)$ & $\mathrm{Na}^{*} 10^{-3}\left(\mathrm{~mol} / \mathrm{m}^{2} \cdot \mathrm{s}\right)$ & $K_{G}\left(k g / m^{3} \cdot s\left(k N / m^{2}\right)\right.$ \\
\hline 1 & 290 & 55.564 & 175.3678 & 0.073214 & 0.148201 & 0.000113 \\
\hline 2 & 810 & 125.631 & 175.3678 & 0.073214 & 0.43263 & 0.000127 \\
\hline 3 & 290 & 14.21 & 175.4981 & 0.073268 & 0.174214 & 0.000206 \\
\hline 4 & 810 & 21.06 & 175.4981 & 0.073268 & 0.498366 & 0.000249 \\
\hline 5 & 290 & 73.5266 & 183.8415 & 0.076752 & 0.130538 & 8.93E-05 \\
\hline 6 & 810 & 176.5719 & 183.8415 & 0.076752 & 0.381971 & $9.92 \mathrm{E}-05$ \\
\hline 7 & 290 & 31.2098 & 183.9731 & 0.076807 & 0.155944 & 0.000145 \\
\hline 8 & 810 & 40.581 & 183.9731 & 0.076807 & 0.463645 & 0.000195 \\
\hline 9 & 100 & 20 & 180.1686 & 0.075218 & 0.049225 & 0.000107 \\
\hline 10 & 1000 & 39 & 180.1686 & 0.075218 & 0.591318 & 0.000216 \\
\hline 11 & 550 & 53.185 & 180.0638 & 0.075174 & 0.305876 & 0.000155 \\
\hline 12 & 550 & 28.7705 & 180.3642 & 0.0753 & 0.320372 & 0.000196 \\
\hline 13 & 550 & 26.774 & 171.2891 & 0.071511 & 0.338638 & 0.000211 \\
\hline 14 & 550 & 102.7565 & 184.3118 & 0.076948 & 0.269009 & 0.000109 \\
\hline 15 & 550 & 23.65 & 180.1686 & 0.075218 & 0.323871 & 0.000209 \\
\hline 16 & 550 & 23.65 & 180.1686 & 0.075218 & 0.323871 & 0.000209 \\
\hline 17 & 550 & 23.65 & 180.1686 & 0.075218 & 0.323871 & 0.000209 \\
\hline 18 & 550 & 23.65 & 180.1686 & 0.075218 & 0.323871 & 0.000209 \\
\hline 19 & 550 & 23.65 & 180.1686 & 0.075218 & 0.323871 & 0.000209 \\
\hline 20 & 550 & 23.65 & 180.1686 & 0.075218 & 0.323871 & 0.000209 \\
\hline
\end{tabular}




\subsubsection{Effect of Urea Concentration}

Figure 5 shows the effect of urea concentration on the absorption rate of $\mathrm{SO}_{2}$ at various concentrations in the range $(500-2500 \mathrm{ppm})$ and fixed absorbent temperature $\left(25^{\circ} \mathrm{C}\right)$. It is clear that as the urea concentration increased, the absorption rate increases regularly. Also, a similar effect is obtained at various working temperature (10 $40^{\circ} \mathrm{C}$ ) and fixed $\mathrm{SO}_{2}$ concentration $(1500 \mathrm{ppm})$. When the urea concentration increased, the absorption rate increases, this agrees with the findings in the cases of using dimethylaniline as an absorbent as reported by Basu et al. [27]. The activity of urea solution towards the removal of sulfur dioxide may be due to the possible bonding of two $\mathrm{SO}_{2}$ molecules to each urea molecule [21].

The results of $\mathrm{NO}_{2}$ absorption at various concentrations $(100-1000 \mathrm{ppm})$ and fixed absorbent temperature $\left(25^{\circ} \mathrm{C}\right)$ showed a clear increase in the absorption rate as the urea solution increases. However, beyond $0.4 \mathrm{~mol} / \mathrm{l}$ of urea, the absorption rate decreases especially at lower acid gas concentration. This trend may be attributed to the decrease the diffusivity of gas.

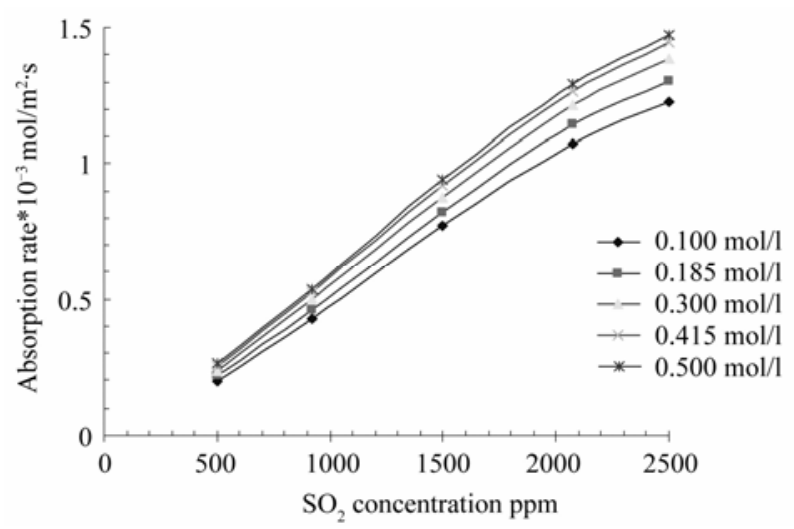

Figure 2. Absorption rate as a function $\mathrm{SO}_{2}$ concentration for various urea concentration.

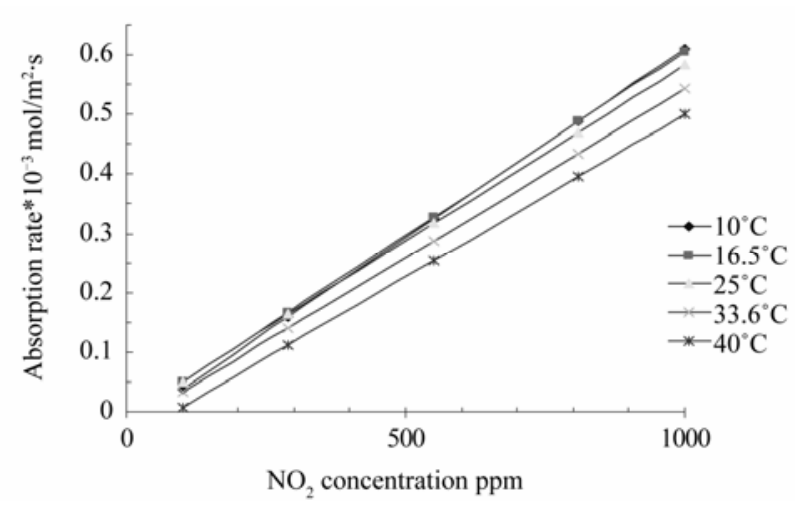

Figure 4. Absorption rate as a function $\mathrm{NO}_{2}$ concentration for different Temperatures of absorbent.
The effect of urea concentration on the absorption rate of $\mathrm{NO}_{2}$ at different absorption temperature in the range $\left(10-40^{\circ} \mathrm{C}\right)$ and constant nitrogen dioxide concentration (500 ppm) is shown in Figure 6. It is clear that as the urea concentration increased, the absorption rate increases. The activity of urea solution toward the removal of $\mathrm{NO}_{2}$ may be due to fast bonding of $\mathrm{NO}_{2}$ with urea molecules.

\subsubsection{Effect of Temperature of Absorbent}

The effect of the temperature of the absorbent on the absorption rate of $\mathrm{SO}_{2}$ is shown in Figure 7 at constant acid gas concentration and various urea concentrations in the range of $(0.1-0.5) \mathrm{mol} / \mathrm{l}$. The absorption rate is found to decrease considerably with increasing the temperature. At constant urea concentration and various $\mathrm{NO}_{2}$ concentration in the range of $\mathrm{SO}_{2}(500-2500) \mathrm{ppm}$ and $\mathrm{NO}_{2}$ $(100-1000) \mathrm{ppm}$, the increase of absorbent temperature lowers the absorption rate of the two acid gases. Such a slightly decreasing rate at higher temperatures may be attributed to the decrease of the solubility and diffusivity of aid gases in urea solution as the temperature increased.

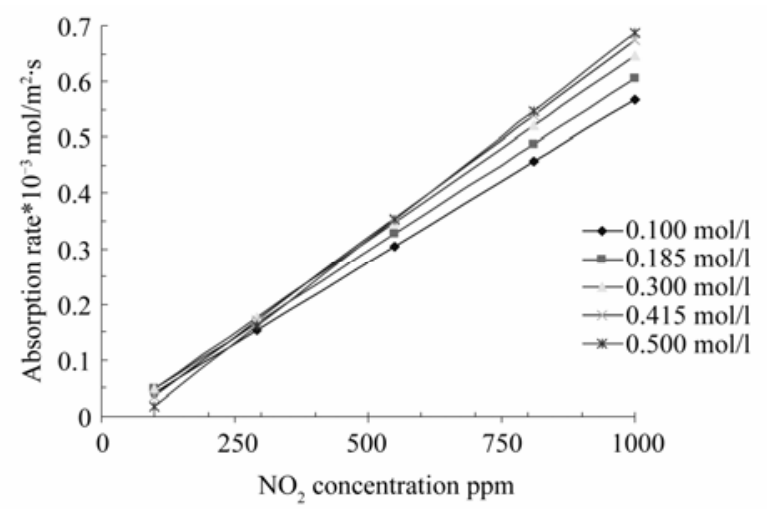

Figure 3. Absorption rate as a function $\mathrm{NO}_{2}$ concentration for different urea concentration.

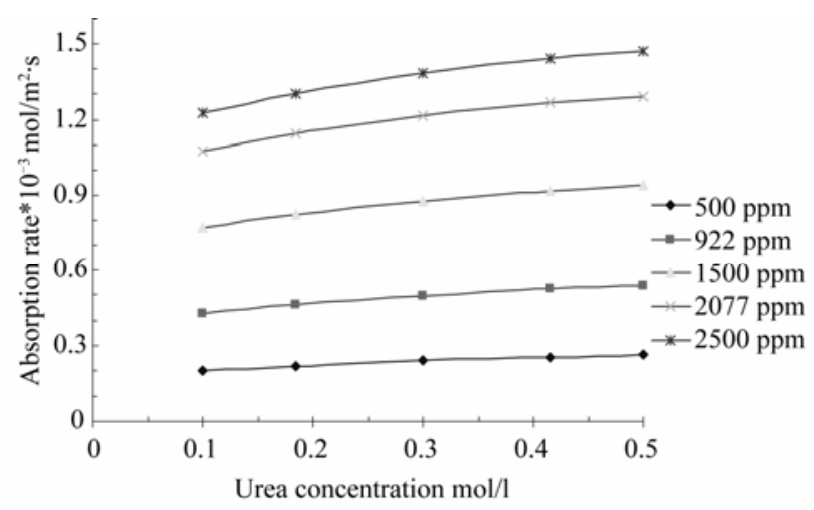

Figure 5. Absorption rate as a function urea concentration for different $\mathrm{SO} 2$ concentration. 


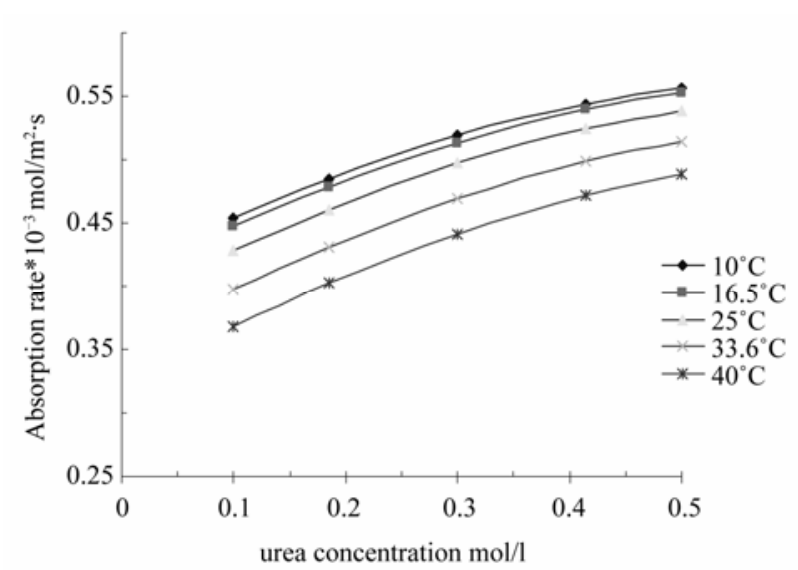

Figure 6. Absorption rate of $\mathrm{NO}_{2}$ as a function urea concentration for various temperatures.

\subsubsection{Effect of $\mathrm{NO}_{2}$ on $\mathrm{SO}_{2}$ Absorption Rate}

Figure 8 shows the absorption rate of $\mathrm{SO}_{2}$ in the presence of various $\mathrm{NO}_{2}$ concentrations at fixed temperature and urea concentration. There existed a minor decrease in the absorption rate decrease with the increase of $\mathrm{NO}_{2}$ concentration. Table 4 shows the experimental data and values of interfacial area of packing for $\mathrm{NO}_{2}$ and $\mathrm{SO}_{2}$. This slight decrease may be due to the fact that the rate of reaction of urea is faster with $\mathrm{NO}_{2}$ than that with $\mathrm{SO}_{2}$.

\subsection{Mass Transfer Coefficient in Packed Tower}

The majority of published results for mass transfer coefficients in packed towers are for rather small laboratory units of $50-250 \mathrm{~mm}$ diameter, and there is still some uncertainty in extending these data for use in industrial units. One of the great difficulties in correlating the performance of packed towers is the problem of assessing the effective wetted area for interface transfer. It is convenient to consider separately the conditions where the gas film controls the process, and then where the liquid film controls [18].

\subsubsection{Postulating the Model}

The mass transfer correlation is usually determined by using Buckingham method for dimensional analysis. The mass transfer coefficient is a function of more variable effect on this important parameter in packed bed column. The basic equation relating the variables is

$$
K_{G}=f\left(d p D_{A B} G^{\prime} \mu_{g} \rho_{g} H\right)
$$

The variable and the dimensional constant believed to be involved and their dimensions in the engineering system are given below

$$
\begin{aligned}
& \text { Mass transfer coefficient }=K_{G}=L / T \\
& \text { Gas density }=\rho_{g}=(M / L)
\end{aligned}
$$

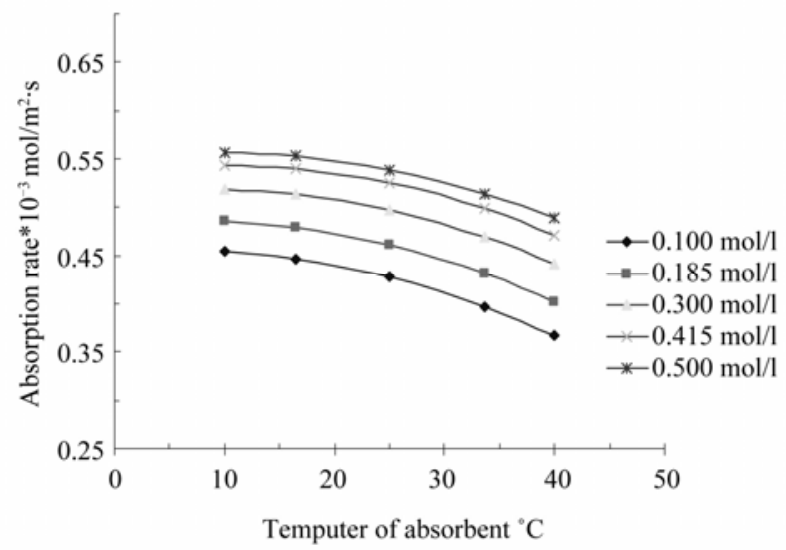

Figure 7. Absorption rate of $\mathrm{SO}_{2}$ as a function of temperature of absorbent for various urea concentrations.

$$
\begin{aligned}
& \text { Gas viscosity }=\mu_{g}=(M / L . T) \\
& \text { Diffusivity of gas }=D_{A B}=\left(L^{2} / T\right) \\
& \text { Packing size }=d p=(L) \\
& \text { Height of packing }=H=(L) \\
& \text { Mass velocity of gas } G^{\prime}=\left(M / T \cdot L^{2}\right)
\end{aligned}
$$

According to Buckingham theory

$$
P=n-m=7-3=4
$$

$P$ is equal to number of dimensionless group Choosing the three virtual variable

$$
\begin{aligned}
& d p=L \quad L=d p \\
& D_{A B}=L^{2} / T \quad T=d p^{2} / D_{A B} \\
& \rho_{g}=M / L^{3} \quad M=\rho_{g} d p^{3}
\end{aligned}
$$

$\prod_{1}=\left(K_{G} d p / D_{A B}\right)$ this dimension is Sherwood number

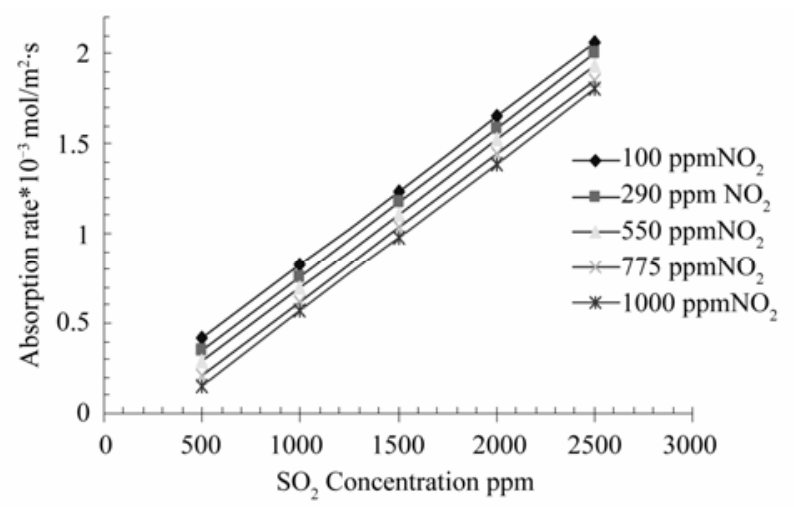

Figure 8. Absorption rate as a function $\mathrm{SO}_{2}$ concentration for various $\mathrm{NO}_{2}$ concentrations. 
Table 4. Experimental results of $\mathrm{SO}_{2}$ and $\mathrm{NO}_{2}$ absorption and values of interfacial area of packing.

\begin{tabular}{|c|c|c|c|c|c|c|c|c|c|c|}
\hline Run & $\begin{array}{c}\text { Inlet } \mathrm{SO}_{2} \\
\text { ppm }\end{array}$ & $\begin{array}{c}\text { Outlet } \mathrm{SO}_{2} \\
\text { ppm }\end{array}$ & $\begin{array}{c}\text { Inlet } \mathrm{NO}_{2} \\
\text { ppm }\end{array}$ & $\begin{array}{c}\text { Outlet } \mathrm{NO}_{2} \\
\text { ppm }\end{array}$ & $\begin{array}{c}\mathrm{a}_{\mathrm{p}} \\
\mathrm{m}^{2} / \mathrm{m}^{3}\end{array}$ & $\begin{array}{l}a_{m} \\
m^{2}\end{array}$ & $\begin{array}{c}\mathrm{Na} \mathrm{SO}_{2} \\
\mathrm{mmol} / \mathrm{m}^{2} \cdot \mathrm{s}\end{array}$ & $\begin{array}{c}\mathrm{Na} \mathrm{NO}_{2} \\
\mathrm{mmol} / \mathrm{m}^{2} \cdot \mathrm{s}\end{array}$ & $\begin{array}{c}\mathrm{Kg}\left(\mathrm{SO}_{2}\right) \\
\mathrm{m} / \mathrm{s}\end{array}$ & $\begin{array}{c}\mathrm{Kg}\left(\mathrm{NO}_{2}\right) \\
\mathrm{m} / \mathrm{s}\end{array}$ \\
\hline 1 & 2000 & 398.6 & 775 & 158.8 & 184.066 & 0.07684 & 0.9503 & 0.3710 & 0.000146 & 0.0001 \\
\hline 2 & 1000 & 297.5 & 775 & 141.1 & 184.066 & 0.07684 & 0.4168 & 0.3823 & 0.00011 & 0.0001 \\
\hline 3 & 2000 & 294 & 225 & 56.09 & 184.066 & 0.07684 & 1.0124 & 0.1061 & 0.000174 & $9.03 \mathrm{E}-5$ \\
\hline 4 & 2000 & 650.5 & 775 & 247.2 & 183.794 & 0.07673 & 0.8020 & 0.3317 & 0.000102 & 7.44E-05 \\
\hline 5 & 2000 & 121.2 & 775 & 106.0 & 176.470 & 0.07367 & 1.1629 & 0.4205 & 0.000265 & 0.000135 \\
\hline 6 & 1000 & 262.5 & 225 & 57.84 & 176.352 & 0.07362 & 0.4568 & 0.1050 & 0.000126 & $9.22 \mathrm{E}-05$ \\
\hline 7 & 2000 & 321.2 & 225 & 80.28 & 176.352 & 0.07362 & 1.0398 & 0.0910 & 0.000173 & $6.99 \mathrm{E}-05$ \\
\hline 8 & 1000 & 327.5 & 775 & 148.8 & 176.470 & 0.07367 & 0.4162 & 0.3774 & 0.000105 & 0.000112 \\
\hline 9 & 1000 & 169 & 225 & 206.1 & 176.231 & 0.07357 & 0.5150 & 0.0118 & 0.000168 & 5.94E-06 \\
\hline 10 & 1000 & 338.7 & 225 & 68.68 & 183.916 & 0.07678 & 0.3927 & 0.0983 & $9.81 \mathrm{E}-05$ & 7.72E-05 \\
\hline 11 & 2000 & 461.2 & 775 & 222.2 & 176.470 & 0.07367 & 0.9524 & 0.3328 & 0.000139 & $8.47 \mathrm{E}-05$ \\
\hline 12 & 2000 & 60 & 225 & 39.78 & 176.231 & 0.07357 & 1.2024 & 0.1117 & 0.000332 & 0.000118 \\
\hline 13 & 2000 & 511.2 & 225 & 87.39 & 184.066 & 0.07684 & 0.8835 & 0.0828 & 0.000123 & $6.15 \mathrm{E}-05$ \\
\hline 14 & 1000 & 247.5 & 775 & 59.17 & 183.794 & 0.07673 & 0.4472 & 0.1041 & 0.000127 & $8.7 \mathrm{E}-05$ \\
\hline 15 & 1000 & 390 & 775 & 197.3 & 184.034 & 0.07683 & 0.3620 & 0.3554 & $8.52 \mathrm{E}-05$ & $8.9 \mathrm{E}-05$ \\
\hline 16 & 1000 & 200 & 775 & 41.23 & 176.427 & 0.07365 & 0.4953 & 0.4510 & 0.000152 & 0.000199 \\
\hline 17 & 2500 & 345 & 550 & 134.7 & 180.191 & 0.07522 & 1.3063 & 0.2557 & 0.000183 & $9.34 \mathrm{E}-05$ \\
\hline 18 & 1500 & 367.5 & 1000 & 194.2 & 180.364 & 0.0753 & 0.6858 & 0.4761 & 0.00013 & 0.000109 \\
\hline 19 & 1500 & 82.5 & 550 & 20.68 & 179.971 & 0.07513 & 0.8603 & 0.3256 & 0.000269 & 0.000218 \\
\hline 20 & 1500 & 407.5 & 550 & 145.9 & 187.602 & 0.07832 & 0.6360 & 0.2487 & 0.000116 & $8.46 \mathrm{E}-05$ \\
\hline 21 & 500 & 113.5 & 100 & 57.97 & 180.191 & 0.07522 & 0.2342 & 0.3026 & 0.000137 & 0.000149 \\
\hline 22 & 1500 & 156.6 & 550 & 17.79 & 180.063 & 0.07517 & 0.8148 & 0.0530 & 0.000209 & 0.000115 \\
\hline 23 & 1500 & 442.5 & 550 & 162.7 & 180.201 & 0.07523 & 0.6410 & 0.2382 & 0.000113 & $8.09 \mathrm{E}-05$ \\
\hline 24 & 1500 & 97.5 & 550 & 23.87 & 171.910 & 0.07177 & 0.8911 & 0.3236 & 0.000265 & 0.000218 \\
\hline 25 & 1500 & 265.5 & 550 & 85.47 & 180.191 & 0.07522 & 0.7483 & 0.2857 & 0.00016 & 0.000124 \\
\hline 26 & 1500 & 265.5 & 550 & 85.47 & 180.191 & 0.07522 & 0.7483 & 0.2857 & 0.00016 & 0.000124 \\
\hline 27 & 1500 & 265.5 & 550 & 85.47 & 180.191 & 0.07522 & 0.7483 & 0.2857 & 0.00016 & 0.000124 \\
\hline 28 & 1500 & 265.5 & 550 & 85.47 & 180.191 & 0.07522 & 0.7483 & 0.2857 & 0.00016 & 0.000124 \\
\hline 29 & 1500 & 265.5 & 550 & 85.47 & 180.191 & 0.07522 & 0.7483 & 0.2857 & 0.00016 & 0.000124 \\
\hline
\end{tabular}

$\prod_{2}=\left(\mu_{g} / \rho_{g} D_{A B}\right)$ this dimension is Schmidt number

$\prod_{3}=\left(G^{\prime} d p / \mu_{g}\right)$ this dimension is Reynolds number

$$
\prod_{4}=(d p / H)
$$

These four dimensionless groups are frequently used in mass transfer coefficient correlation. Functionally, their relation may be expressed as

$$
\begin{aligned}
& \Phi(S h, R e, S c,(d p / H))=0 \\
& \text { Or as } S h=\Phi_{1}(\operatorname{Re}, S c,(d p / H))
\end{aligned}
$$

It has been found that these dimensionless groups may be correlated well by equation of the type

$$
\left(K_{G} d p / D_{A B}\right)=K\left(G^{\prime} d p / \mu_{g}\right)^{a}\left(\mu_{g} / \rho_{g} D_{A B}\right)^{b}(d p / H)^{c}
$$

In which $K, a, b, c$ are experimentally determined by using Statistical- software Windows version 5.5.

$$
S h=4.19 * 10^{-2} *\left(G^{\prime} d p / \mu_{g}\right)^{0.866}\left(\mu_{g} / \rho_{g} D_{A B}\right)^{0.599}(d p / H)^{0.850}
$$

Finally the model can be expressed as in the equation:

$$
\operatorname{Sh}(H / d p)^{1.2}=4.19 * 10^{-2} \operatorname{Re}^{0.87} S c^{0.60}
$$


Correlation coefficient, $R^{2}=0.9838$

Variance explained, $S=96.789 \%$

\subsubsection{Comparison of the Model with Other Correlation}

The proposed model expressed by Equation (40) is compared with Sherwood equation [22];

$$
S h=\beta^{\prime} \operatorname{Re}^{0.83} S c^{0.44}
$$

where the $\beta^{\prime}=0.021$ to 0.027 a mean value of 0.023 is used; The Kramer's equation [23]:

$$
S h=0.069 R e^{0.59} S c^{0.33}
$$

and Weisweiler, et al. [32] equation:

$$
S h=0.3 \operatorname{Re}^{0.8} S^{1 / 3}(d p / H)
$$

These equations were applied for the operating variables of the present work for acid gas concentration between $(100$ - 2500) ppm and temperature range (10 $40)^{\circ} \mathrm{C}$. The comparison indicated a reasonable agreement with Kramer's equation while deviated strongly with those obtained by Weisweiler using the Sherwood Equation (41). The absorption rate values obtained in the present work for various acid gases concentrations and tempera- tures were in the range of $0.320 \times 10^{-3}-1.16 \times 10^{-3}$ $\mathrm{mol} / \mathrm{m}^{2} \cdot \mathrm{s}$. These values compares well with the published data from several investigators using various absorption designs [17,20,24-27]. The details of the comparison can be seen in Table 5 .

\section{Conclusions}

The following conclusions can be drawn from the present work:

1) The absorption rate of $\mathrm{SO}_{2}$ increases when the temperature of absorbent (urea solution) decreases and increases as the concentration of absorbent solution.

2) The presence of $\mathrm{NO}_{2}$ in the effluent gas stream in addition to $\mathrm{SO}_{2}$ decreases the absorption rate of $\mathrm{SO}_{2}$ in urea solution this may be due to the fast reaction of $\mathrm{NO}_{2}$ with urea as compared with $\mathrm{SO}_{2}$.

Table 5. Comparison of absorption rate values with some published results.

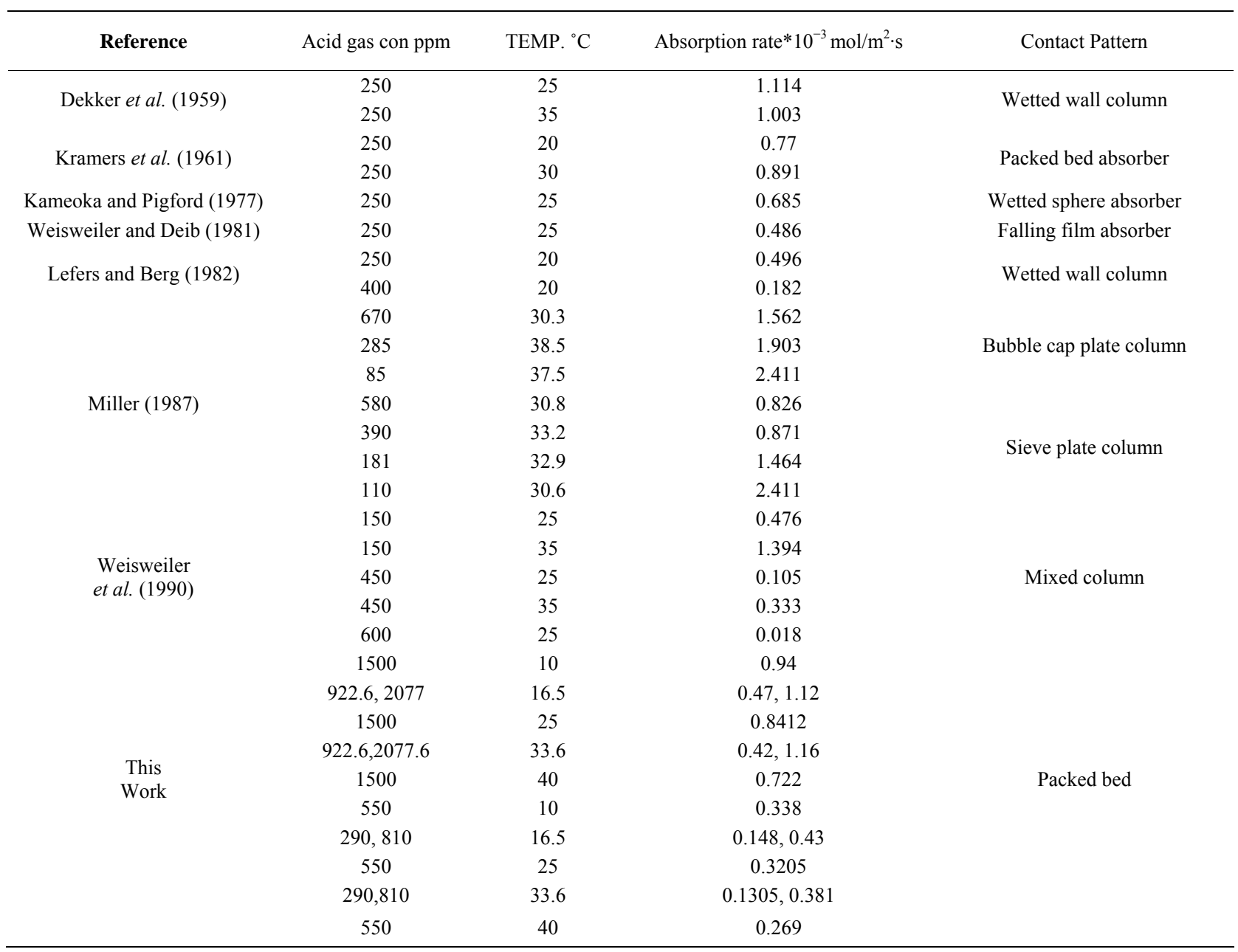


3) The absorption rate of $\mathrm{NO}_{2}$ decreases at higher urea concentration $0.4 \mathrm{~mol} / 1$ for low gas concentration $\mathrm{ppm}$ due to the decrease the diffusivity of gas.

4) The variables that affect the absorption rates of $\mathrm{SO}_{2}$ and $\mathrm{NO}_{2}$ in urea solution can be formulated using the dimensionless group analysis and may be expressed by the following equation

$$
\mathrm{Sh}(\mathrm{H} / \mathrm{dp})^{1.2}=4.19^{*} 10^{-2} \mathrm{Re}^{0.87} \mathrm{Sc}^{0.56}
$$

This model agrees well with Kramer's Equation (42) with a correlation coefficient, $\mathrm{R}$, of 0.9838 .

\section{Acknowledgements}

One of us (M.M.B.) is grateful for the Institute of International Education, IIE, for granting him a scholarship as a visiting Professor at Montclair State University in New Jersey.

\section{REFERENCES}

[1] T. Denmead, B. Macdonald, I. White, G. Bryant, D. Griffith, A. Kinsela and M. Melville, "Links between Emissions of Nitrogen and Sulfur Gases from Acid Sulfate Soils: Field Evidence," 19th World Congress of Soil Science, Soil Solutions for a Changing World, Brisbane, 2010.

[2] P. G. Cheremisionff and R. A. Young, "Air Pollution Control and Design Hand Book," Marcel Dekker, Inc. New York, 1977.

[3] C. M. Hansen, "Control of Sox Emission," Industrial and Engineering Chemistry Product Research and Development, Vol. 16, 1977, p. 266. doi:10.1021/i360063a016

[4] V. S. Soldatov, A. V. Kashinskii, T. A. Korshunova and V. I. Martinovich, "Removal of Nitrogen Dioxide from Air Using Aqueous Carbamide on a Fibrous Ion Exchanger," Chemistry and Material Science, Vol. 41, No. (Suppl. 2), 2005, pp. 760-763.

[5] U.S.DOE, "Advance Technology for the Control of Sulfur Dioxide Emission from Coal-Fired Boilers," Clean Coal Technology Conference, Knoxville, 1999.

[6] B. H. Potter and T. L. Craig, "Control Sulfur Oxide," Chemical Engineering Programme, Vol. 68, No. 8, 1972, p. 53.

[7] F. S. Chalmer, "Evaluation of Regenerable FGD Process," AIChE Journal, Vol. 23, No. 4, 1977, pp. 538-544.

[8] E. Bekassy-Molnar, E. Marki and J. G. Majeed, "Sulphur Dioxide Absorption in Air-Lift-Tube Absorbers by Sodium Citrate Buffer Solution," Chemical Engineering and Processing, Vol. 44, No. 9, 2005, pp. 1039-1046. doi:10.1016/j.cep.2005.02.001

[9] J. H. Russel, J. I. Paige and D. L. Paulson, "Evaluation of Some Solid Oxides as Sorbent of $\mathrm{SO}_{\mathrm{x}}$," Rep Invest-U.S Bur. Mines R1 7582, 1971.

[10] P. G. Gray, "A Fundamental Study on the Removal of Air Pollutants (Sulfur Dioxide, Nitrogen Dioxide and Carbon Dioxide) by Adsorption on Activated Carbon," Gas
Separation \& Purification, Vol. 7, No. 4, 1993, pp. 213224. doi:10.1016/0950-4214(93)80020-W

[11] P. Daniell, A. Soltani-Ahmadi and H. O. Kono, "Reaction Kinetics of the $\mathrm{SO}_{2}-\mathrm{CaO}$ System-Pore Closure Model," Powder Technology, Vol. 55, 1988, pp. 75-78. doi:10.1016/0032-5910(88)80090-1

[12] EPAU.S Environmental Protection Agency, "Alternative Control Techniques Document-Nitric and Adipic Acid," EPA Publication, No. 450/3-91-026, 1991.

[13] European Commission, "Technical Note on Best Available Technologies Not Entailing Excessive Costs for Heavy Metal Emissions from Non-Ferrous Industrial Plants," Final Report - May 1991, ECSC-EC-EAEC, Brussels Luxembourg, 1994.

[14] S. H. Zhang, L. L. Cai, X. H. Mi, J. L. Jiang and W. Li, "NO${ }_{x}$ Removal from Simulated Flue Gas by Chemical Absorption - Biological Reduction Integrated Approach in a Biofilter," Environment Science and Technology, Vol. 42, No. 10, 2008, pp. 3814-3820. doi: $10.1021 / \mathrm{es} 800200 \mathrm{~g}$

[15] G. A. Streuli and P. R. Averell, "The Analytical Chemistry of Nitrogen and It Is Compound, Part I," John Wiley and Sons. Inc, New York, 1970.

[16] D. G. Montgomery, "Design and Analysis of Industrial Experiments," John Wiley and Sons, New York, 1976.

[17] W. Weisweiler and K. H. Deib, "Measurement of Absorption Rate of $\mathrm{NO}_{2}$ and $\mathrm{SO}_{2}$ in Water in a Falling Film Absorber," Chemistry Engineering, Vol. 4, 1981, p. 79.

[18] J. M. Coulson and J. F. Richardson, "Chemical Engineering," Vol. 2, 4th Edition, Pergamon Press, Oxford, 1991.

[19] R. K. Basu and B. K. Dutta, "Kinetic of Absorption of Sulfur Dioxide in Dimethylaniline Solution," Canadian Journal of Chemistry Engineering, Vol. 65, No. 1, 1987, pp. 27-35. doi:10.1002/cjce.5450650106

[20] J. B. Lefers and P. I. Berg, "Absorption of $\mathrm{NO}_{2}-\mathrm{N}_{2} \mathrm{O}_{4}-$ $\mathrm{SO}_{2}$ in to Dilute and Concentrated Aqueous Solution," Chemistry Engineering Journal, Vol. 23, 1981, p. 211.

[21] R. E. Khoma, M. I. Gavrilenko and V. I. Nikitin, "Interaction of Sulfur Dioxide with Aqueous Solutions of Amides," Zhurnal Obshchei Khimii, Vol. 75, No. 5, 2005, pp. 771-777.

[22] T. K. Sherwood, R. L. Pigford and R. L. Wilke, "Mass Transfer," McGraw-Hill, New York, 1975.

[23] H. Kramers, M. P. Blind and E. Sneck, "Absorption of $\mathrm{NO}_{2}, \mathrm{SO}_{2}, \mathrm{~N}_{2} \mathrm{O}_{4}$ by Water Jet," Chemistry Engineering Science, Vol. 14, No. 1, 1961, pp. 115-123. doi:10.1016/0009-2509(61)85062-8

[24] W. Weisweiler, K. Eidam, M. Thiemann and K. W. Wiegand, "Absorption of $\mathrm{NO}_{2} / \mathrm{N}_{2} \mathrm{O}_{4}$ in Nitric Acid, Gas," Chemistry Engineering and Technology, Vol. 13, No. 3, 1990, pp. 97-101. doi:10.1002/ceat.270130113

[25] W. A. A. Dekker, E. Snoeck and Kramer's. "The Rate of Absorption of Acid Gas in Water and Aqueous Solution," Chemistry Engineering Science, Vol. 11, 1951, p. 61. doi:10.1016/0009-2509(59)80073-7 
[26] Y. Kameoka and R. L. Pigford, "Absorption of $\mathrm{NO}_{2}$ in Water Sulfuric Acid, Sodium Hydroxide and Alkaline Sodium Sulfite Aqueous Solution," Industrial \& Engineering Chemistry Fundamentals, Vol. 16, No. 4, 1977, p. 153.
[27] D. N. Miller, "Mass Transfer in Nitric Acid," AIChE Journal, Vol. 33, No. 8, 1987, p. 1351. doi:10.1002/aic.690330812 